\title{
Cell Morphology on Poly(methyl methacrylate) Microstructures as Function of Surface Energy
}

\author{
Matthias Katschnig, ${ }^{1}$ Boris Maroh,, ${ }^{2}$ Natascha Andraschek, ${ }^{2}$ Sandra Schlögl, ${ }^{2}$ \\ Ulrike Zefferer, ${ }^{3}$ Elisabeth Bock, ${ }^{4}$ Gerd Leitinger ${ }^{(D)}{ }^{4}$ Christa Trattnig, ${ }^{3}$ Maria Kaufmann, ${ }^{5}$ \\ Werner Balika, ${ }^{5}$ Clemens Holzer, ${ }^{1}$ Ute Schäfer, ${ }^{3}$ and Silke Patz $\mathbb{D}^{3}$ \\ ${ }^{1}$ Montanuniversität Leoben, Austria \\ ${ }^{2}$ Polymer Competence Center Leoben GmbH, Austria \\ ${ }^{3}$ Research Unit for Experimental Neurotraumatology, Department of Neurosurgery, Medical University, Graz, Austria \\ ${ }^{4}$ Medical University of Graz, Gottfried Schatz Research Center, Austria \\ ${ }^{5}$ STRATEC Consumables GmbH, Austria
}

Correspondence should be addressed to Silke Patz; silke.patz@medunigraz.at

Received 7 January 2019; Revised 22 March 2019; Accepted 7 April 2019; Published 2 May 2019

Academic Editor: Wen-Cheng Chen

Copyright ( 2019 Matthias Katschnig et al. This is an open access article distributed under the Creative Commons Attribution License, which permits unrestricted use, distribution, and reproduction in any medium, provided the original work is properly cited.

Whilst the significance of substrate topography as a regulator of cell function is well established, a systematic analysis of the principles underlying this is still unavailable. Here we evaluate the hypothesis that surface energy plays a decisive role in substratemediated modulation of cell phenotype by evaluation of cell behaviour on synthetic microstructures exhibiting pronounced differences in surface energy. These microstructures, specifically cubes and walls, were fabricated from a biocompatible base polymer, poly(methyl methacrylate), by variotherm injection molding. The dimensions of the cubes were $1 \mu \mathrm{m} \times 1 \mu \mathrm{m} \times 1 \mu \mathrm{m}$ (height $\mathrm{x}$ width $\mathrm{x}$ length) with a periodicity of 1:1 and 1:5 and the dimensions of the walls $1 \mu \mathrm{m} \times 1 \mu \mathrm{m} \times 15 \mathrm{~mm}$ (height $\mathrm{x}$ width $\mathrm{x}$ length) with a periodicity of 1:1 and 1:5. Mold inserts were made by lithography and electroplating. The surface energy of the resultant microstructures was determined by static contact angle measurements. Light scanning microscopy of the morphology of NT2/D1 and MC3T3-E1 preosteoblast cells cultured on structured PMMA samples in both cases revealed a profound surface energy dependence. "Walls" appeared to promote significant cell elongation, whilst a lack of cell adhesion was observed on "cubes" with the lowest periodicity. Contact angle measurements on walls revealed enhanced surface energy anisotropy ( $55 \mathrm{mN} / \mathrm{m} \mathrm{max} ., 10$ $\mathrm{mN} / \mathrm{m} \mathrm{min}$.) causing a lengthwise spreading of the test liquid droplet, similar to cell elongation. Surface energy measurements for cubes revealed increased isotropic hydrophobicity $\left(87^{\circ}\right.$ max., $\left.\mathrm{H}_{2} \mathrm{O}\right)$. A critical water contact angle of $\leq 80^{\circ}$ appears to be necessary for adequate cell adhesion. A "switch" for cell adhesion and subsequently cell growth could therefore be applied by, for example, adjusting the periodicity of hydrophobic structures. In summary cell elongation on walls and a critical surface energy level for cell adhesion could be produced for NT2/D1 and MC3T3-E1 cells by symmetrical and asymmetrical energy barrier levels. We, furthermore, propose a water-drop model providing a common physicochemical cause regarding similar cell/droplet geometries and cell adhesion on the investigated microstructures.

\section{Introduction}

It is well established that cellular functions including proliferation, migration, differentiation, and motility are regulated by genetic factors, cellular communication, and chemical, metabolic, and protein-based messengers $[1,2]$. Interactions with the extracellular matrix (ECM), furthermore, influence cell behaviour and have become increasingly important for the understanding of cell development $[2,3]$. Alongside the impact of physicochemical matrix composition, various studies have demonstrated that topography alone can significantly modulate cell function [4-7].

The three-dimensional topography of the ECM is created by interwoven fibrillar proteins (e.g., collagens, elastins, 
fibronectins, and laminins) embedded within a network of proteoglycans $[2,8]$. The proteins of the ECM and basement membrane, as well as their interconnecting pores, exhibit microscale and nanoscale dimensions [9] and collectively produce a complex environment with hierarchically structured microscale and nanoscale pores, pillars, grooves, and ridges $[10,11]$. The ECM, moreover, contains nonmatrix proteins, such as soluble growth factors. Together these features of the ECM provide mechanical, chemical, and physical cues that modulate cell behaviour and functionality $[9,12,13]$.

Interventional modulation of specific cell functions through the use of synthetic micro- and nanostructures with architecture and geometry mimicking specific features of the ECM is an attractive idea. Microstructures could thereby be categorized by a dimensional scale above $1 \mu \mathrm{m}$ and nanostructures beyond $1 \mu \mathrm{m}$. Several studies have shown that interaction of a variety of cell types with micro- and nanostructures generally results in increased adhesion and proliferation. This has been shown for fibroblasts, smooth muscle cells, endothelial cells, osteoblasts, and mesenchymal stem cells cultured on islands [14-16], columns [17], fibres [18-22], or angular structures [23].

We hypothesized that variable surface energy associated with different surface topographies plays a decisive role in the observed differential modulation of cell behaviour. To test this, we created polymeric microstructures with pronounced differences in surface energy. These are basically manufactured on an industrial scale, mainly by hot embossing [2428] or injection molding [27,29-34]. The former is defined as the stamping of a pattern into a softened polymer at elevated temperatures. Its main advantages are precise replication of even nanotopographies and low material strain due to low shearing. Its main disadvantage is a long cycle time up to half an hour.

Injection molding comprises the injection of molten plastic into a mold under high pressure. The material for the part is fed into a heated barrel, molten and mixed, and forced into a mold cavity, where it is cooled and solidified to the exact shape of the cavity [35]. For the replication of microstructured surfaces, the standard injection molding process is adapted using a microstructured stamper as a mold cavity insert fixed by a frame. The main advantages of injection molding are high replication numbers at low cycle times and precise microstructure demolding, whilst the main disadvantages are high machine and mold costs.

To achieve large numbers of products, both techniques produce replicates of the so-called stamper (the negative of the desired structure) many times. The stampers can be fabricated in several ways, including micromachining by CNC (computerized numerical control) milling and different forms of LIGA (lithography electroplating and molding).

Due to the fast freezing of the polymer melt filling the negative topography and thus a lack of demolding quality, a variotherm system (rapid heating/cooling system of the mold) is commonly used to create microstructures by injection molding [27, 31, 36-38]. The basic variotherm process usually comprises rapid elevation of mold temperature above the glass transition temperature of polymers to extend the liquid period of polymer melts during the filling phase [39].
Different types of variotherm process have been developed, for instance, incorporating inductive heating or electrical resistance heating with cooling by liquid cold media [39].

\section{Materials and Methods}

2.1. Base Polymer Selection. Poly(methyl methacrylate) (PMMA), also known by the trade name Plexiglas $\odot$, was selected as polymeric cell niche based on our previous work [40]. PMMA generally exhibits hydrophilic characteristics due to the ester groups in its macromolecular backbone (molecular formula: $\left.\mathrm{C}_{5} \mathrm{O}_{2} \mathrm{H}_{8}\right)_{\mathrm{n}}$ ), is sufficiently and optically transparent to permit cell observation by microscopy, and exhibits good casting qualities for microstructuring [41]. Medical grade material (DELPET 70NH, Asahi Kasei Chemicals Corporation, Japan) delivered in granule form and ready for injection molding was used. The melt flow rate is reported to be $1.8 \mathrm{~g} / 10 \mathrm{~min}\left(230^{\circ} \mathrm{C}, 3.8 \mathrm{~kg}\right)$ and the bulk density $1.19 \mathrm{~g} / \mathrm{cm}^{3}$. The tensile modulus is reported to be $3300 \mathrm{MPa}$ and the tensile strength at break $67 \mathrm{MPa}$; thus the material is very stiff. The recommended barrel $\left(210^{\circ} \mathrm{C}-250^{\circ} \mathrm{C}\right)$ and mold temperatures $\left(50^{\circ} \mathrm{C}-70^{\circ} \mathrm{C}\right)$ were observed. Prior to molding, the material was predried at $90^{\circ} \mathrm{C}$ for $4 \mathrm{~h}$ using a dehumidifying drier. Standard polystyrene (PS) cell culture dishes were used for reference purposes.

2.2. Mold Insert Fabrication. Nickel mold inserts comprising the microstructure negative were fabricated by the LIGA process and remained uncoated and untreated to avoid sample contamination.

2.3. Variotherm Injection Molding. Microstructure fabrication was performed at STRATEC Consumables GmbH (Former Sony DADC BioSciences GmbH, Austria) in a clean room environment by injection compression molding using a fully electric injection molding machine (ENGEL e-motion 100, ENGEL AUSTRIA GmbH, Austria). The mold used featured a hot runner system and was evacuated before injection. A company-internal standard process parameter set optimized for optical clarity and replication of structures was deployed.

A variotherm process was implemented by electrical resistance heating based on previous results showing that variotherm processes are very useful for high aspect ratio microstructure replication [39, 42, 43]. Molded slide sterility was maintained by aseptic packaging in sterile containers.

\subsection{Evaluation of Demolding Quality and Slide Holding} Concept. Demolding quality of the injection molded slides was evaluated by Scanning Electron Microscopy (SEM) and Atomic Force Microscopy (AFM). For SEM we used a Zeiss DSM950 scanning electron microscope (Carl Zeiss AG, Germany) employing a secondary electron detector and an acceleration voltage of $10 \mathrm{kV}$. Polymer samples were sputter-coated with gold to ensure surface conductivity. The employed sputter coater was a Bal-Tec SCD 500 (Capovani Brothers Inc., USA) and the sputtered gold layer thickness was approximately $15 \mathrm{~nm}$ based on sputter time (60 s) 
and current $(40 \mathrm{~mA})$. Postdata processing was performed using Paint.NET@ v4 (dotPDN LLC, USA). For AFM we used a Dimension 3100 Series AFM (Digital Instruments Incorporated, USA) in tapping mode. The respective scan area was $5 \times 5 \mu \mathrm{m}^{2}$; evaluated area was $4 \times 4 \mu \mathrm{m}^{2}$ to avoid fringe effects. Tip velocity was $10 \mu \mathrm{m} / \mathrm{s}$, average amplitude set point $1.5 \mathrm{~V}$, and average drive amplitude $250 \mathrm{mV}$. As cantilever tip, a Veeco OTESPA Wafer silicon probe $\left(\mathrm{k}=42 \mathrm{~N} / \mathrm{m}, \mathrm{f}_{0}=300\right.$ $\mathrm{kHz}$ ) (Asylum Research, USA) for general samples, was used. Data was collected using NanoScope Version 5.12 (Digital Instruments Veeco Metrology Group, USA) and processed using Gwyddion v2.26 (Czech Metrology Institute, Czech Republic). The slides were finally incorporated into a Millipore ${ }^{\circledR}$ Millicell $^{\mathrm{TM}}$ slide adapter (Merck KgaA, Germany) for cell culture applications (Figure S1B-C).

2.5. Contact Angle and Surface Energy Measurements. Water contact angles are commonly used to measure overall surface wettability, whilst surface energy differentiates between wettability caused by polar groups and that by disperse forces such as van der Waals attractions.

Contact angle measurements were carried out with a DSA 100 Drop Shape Analysis System (Krüss, Germany) using deionized water and diiodomethane as test liquids. Droplet volume for both test liquids was $2 \mu \mathrm{L}$. In each experiment, a drop was applied to a solid sample (sessile drop) and a cross-sectional image of the drop was captured with a camera and transferred to the drop shape analysis software. Contour recognition was initially carried out based on a grey-scale analysis of the image. In the second step, a geometrical model describing the drop shape was applied to fit the contour of the drop. The Young-Laplace-Fit, which is applicable to ideal sessile drops flattened by their own weight and for contact angles in the range of $10^{\circ}$ to $180^{\circ}$, was thus chosen as basic method. For highly symmetric drop geometry, the polynomial method was preferred [44]. Mean contact angle values were calculated from at least ten individual measurements.

Surface energy was then calculated according to Owens, Wendt, Rabel, and Kaelble $[45,46]$ using the software DSA1 v1.9 (Krüss, Germany). To model and determine the wetting state on the surface, that is, Wenzel regime or Cassie-Baxter regime, we also studied the wetting behaviour of smaller (1 $\mu \mathrm{L})$ and larger $(5 \mu \mathrm{L})$ deionized water droplets. Mean contact angle values were again calculated from at least ten individual measurements. Reproducibility was assured by a maximum standard deviation of $\pm 3^{\circ}$. A nonstructured PMMA slide served as reference. Surface energy calculation software did not facilitate error propagation, so no standard deviation could be displayed.

2.6. UV Sterilization. Ultraviolet (UV) light sterilization for cell culture investigations $\left(1.7 \mathrm{~mW} / \mathrm{cm}^{2}\right.$ for 1 hour $)$ was carried out using a Microbiological Safety Class II Workbench KS9 (Heraeus Holding GmbH, Germany).

2.7. Cell Culture. $5 \times 10^{3} \mathrm{NT} 2 / \mathrm{D} 1$ or MC3T3-E1 cells were seeded into $1 \mathrm{~cm}^{2}$ wells on either structured or nonstructured PMMA provided by STRATEC Consumables GmbH.
NT2/D1 cells were cultured in Dulbecco's modified Eagle's medium supplemented with $10 \%$ fetal bovine serum (FBS) at $37^{\circ} \mathrm{C}$ in $95 \%$ air $/ 5 \% \mathrm{CO}_{2} . \mathrm{MC} 3 \mathrm{~T} 3-\mathrm{E} 1$ cells were cultured in MEM containing $10 \% \mathrm{FBS}$ and $2 \mathrm{mM}$ Glutamate at $37^{\circ} \mathrm{C}$ in $95 \%$ air $/ 5 \% \mathrm{CO}_{2}$. Both cell lines were grown to $70-90 \%$ confluence.

2.8. Cell Staining and Microscopy. For F-actin staining, NT2/D1 and MC3T3-E1 cells were washed twice with PBS following culture for $48 \mathrm{hrs}$ and subsequently fixed with $3 \%$ paraformaldehyde for $10 \mathrm{~min}$ at room temperature (RT) and permeabilized with $0.1 \%$ Triton-X100 for $5 \mathrm{~min}$ at RT. Rhodamine-phalloidin stock solution in methanol with a concentration of $6.6 \mu \mathrm{M}(300$ units/mL) $(540 / 565 \mathrm{~nm}$; Invitrogen) was diluted in PBS (5 $\mu \mathrm{L}$ stock in $200 \mu \mathrm{L}$ PBS) and incubated for $20 \mathrm{~min}$ at RT to stain F-actin bundles. Nuclei were visualized by DAPI counterstaining for $5 \mathrm{~min}$ at RT (stock solution concentration of $5 \mathrm{mg} / \mathrm{mL}, 10.9 \mathrm{mM}$, and working solution concentration of $300 \mathrm{nM})(358 / 461$ $\mathrm{nm}$, Invitrogen). Laser confocal imaging (Zeiss SM 510) was performed using a 10x objective and an excitation wavelength of $488 \mathrm{~nm}$ and $543 \mathrm{~nm}$ with an open aperture.

2.9. Gene Expression Analyses. Cells were cultured as described above, snap-frozen in liquid nitrogen, and stored at $-80^{\circ} \mathrm{C}$ for further analysis. Total RNA was isolated using the RNeasy micro Kit (Qiagen, Germany), according to the manufacturer's instructions. Following RNA quality control by $1.2 \%$ formaldehyde agarose gel electrophoresis, cDNA was synthesized from $200 \mathrm{ng}$ total RNA using the Fermentas First Aid cDNA First Strand Synthesis Kit (Thermo Fisher Scientific, Germany) according to the manufacturer's instructions. Amplicon sizes and primer sequences: NF200 (160 bp), forward: 3'-GAGGAACACCAAGTGGGAGA-5'; reverse: 3'-TTCTGGAAGCGAGAAAGGAA -5'; MAP (319 bp), forward: 3'-TCAGAGGCAATGACCTTACC-5'; reverse: 3'-GTGGTAGGCTCTTGGTCTTT-5'; Tuj1 (359 bp), forward: 3'- GGCAACCAGATCGGGGCCAAGT-5'; reverse: 3'-CCCTGCAGGCAGTCGCAGTTT-5'; U6 (94 bp), forward: 3'-CTCGCTTCGGCAGCACA-5'; reverse: 3'AACGCTTCACGAATTTGCGT-5'. PCR conditions: denaturation at $95^{\circ} \mathrm{C}$ for $5 \mathrm{~min}$ followed by 35 cycles of amplification for NF200 (30 s, $\left.60^{\circ} \mathrm{C}\right), 32$ cycles for MAP2 $\left(30 \mathrm{~s}, 58^{\circ} \mathrm{C}\right), 35$ cycles for Tuj1 $\left(30 \mathrm{~s}, 60^{\circ} \mathrm{C}\right)$, and 35 cycles for U6 $\left(30 \mathrm{~s}, 60^{\circ} \mathrm{C}\right)$. Denaturation $\left(95^{\circ} \mathrm{C}\right)$, annealing, and extension $\left(72^{\circ} \mathrm{C}\right)$ times were all $30 \mathrm{~s}$. Final extension was at $72^{\circ} \mathrm{C}$ for $10 \mathrm{~min}, \mathrm{PCR}$ products were resolved by $2 \%$ agarose gel electrophoresis, and densitometric analysis was performed with Quantity One software (Bio-Rad, Hercules, CA, USA). U6 was used as reference gene.

\section{Results and Discussion}

3.1. Structure Design. We hypothesized that local variations of surface energy by different microstructures play a decisive role in the modulation of the investigated cell types. This hypothesis is based on prior publications; for instance, a surface energy influence on fibroblast growth and spreading was shown by Schakenraad et al. [47] and on osteoblast 


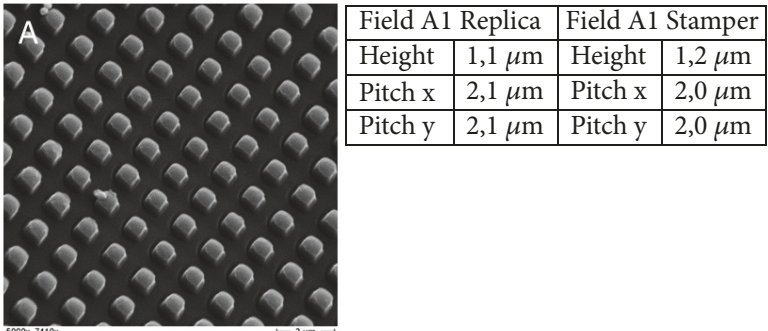

(a)

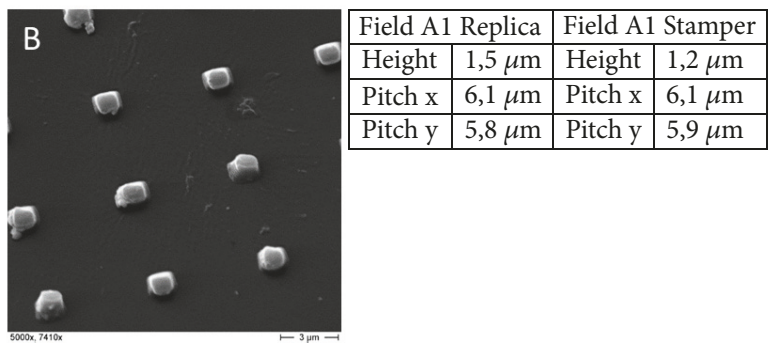

(b)

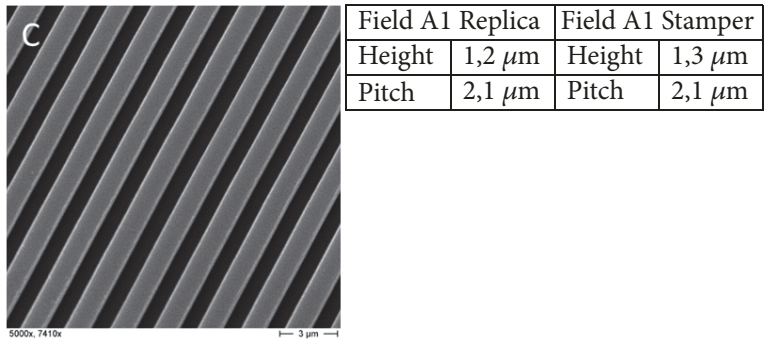

(c)

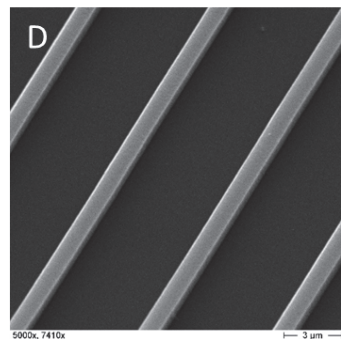

(d)

FIGURE 1: (a)-(d): SEM images of the injection-molded microstructures (left images) and the AFM profile measurements of the injectionmolded microstructures compared according to the stamper (right tables). Pitch measured from center point to center point of structure elements. (a) Cubes P1:1; (b) cubes P1:5; (c) walls P1:1; (d) walls P1:5.

adhesion by Ranella et al. [48]. Our first step in testing this hypothesis was, thus, to establish microstructures with pronounced differences in surface energy.

Cubes and walls were selected to underlie microstructure design based on already published knowledge and technical considerations regarding proper demolding. The dimensions of the cubes were $1 \mu \mathrm{m} \times 1 \mu \mathrm{m} \times 1 \mu \mathrm{m}$ (height $\mathrm{x}$ width $\mathrm{x}$ length) with a periodicity of 1:1 and 1:5 and the dimensions of the walls $1 \mu \mathrm{m} \times 1 \mu \mathrm{m} \times 15 \mathrm{~mm}$ (height $\mathrm{x}$ width $\mathrm{x}$ length) with a periodicity of 1:1 and 1:5. The microstructures were located on a standard microscopy slide of $1 \mathrm{~mm}$ x $25 \mathrm{~mm}$ x $75 \mathrm{~mm}$ (height $\mathrm{x}$ width $\mathrm{x}$ length) on an area of $150 \mathrm{~mm}^{2}$ for each structure field (Figure S1A). The injection-molded slides were examined by SEM and AFM to confirm adequate demolding quality. In general, PMMA is less suitable for proper demolding because of the material's polar nature, which causes it to stick to the stamper. Adequate demolding quality was, nevertheless, achieved even without mold release agents or mold coating, as shown by a comparison of stamper and replica (Figures $1(\mathrm{a})-1(\mathrm{~d})$ ).

\subsection{Evaluation of Surface Energy/Drop Shape Anisotropy.} Parallel ("pa") and perpendicular ("pe") static contact angles to the microstructure were measured to verify the assumed asymmetry of surface energy on microstructures. The microstructure "walls" was, thereby, used as coordinate reference: along walls it was defined as "parallel" $\left(0^{\circ}\right)$ and across walls it was defined as "perpendicular" $\left(90^{\circ}\right)$.

Drop shape anisotropy with respect to surface energy means that contact angles differ depending on the measurement direction. The received contact angles and the derived surface energy values of water and diiodomethane are listed in Table 1; surface energy values alone are shown in Figure 2.
Surfaces with cubes (P1:1, P1:5) and the nonstructured reference surface exhibited "symmetric droplets" indicative of isotropic wetting properties (discontinuous design). Nonstructured reference exhibited typical contact angles as given in [49]. The total surface energy of the PMMA substrate was, however, significantly decreased by the introduction of cubic structures. For P1:5 structures, this decrease was mainly related to a depletion of the dispersing surface energy component. With lower cube spacing (P1:1), the decrease in total surface energy was even more pronounced, since both polar and disperse components were decreased.

In contrast to control and cubes, for which we observed similar wetting in both parallel and perpendicular directions, the wetting properties of wall structures were anisotropic (continuous design), as the contact angles of both test liquids exhibited lower surface energy (hydrophobic properties) parallel to wall direction and higher values (hydrophilic properties) perpendicular to wall structures (Figure 2, Table 1). Particularly for P1:1 walls the water contact angle was $132^{\circ}$ perpendicularly to the structures, whilst it was $59^{\circ}$ parallel to the structure.

The results shown in Table 1 suggest that test liquid droplet spreading along the lengthwise wall direction, which exhibits the higher surface energy, was energetically favoured. In other words, the test liquid tends to wet the structure in a manner similar to a "capillary effect" parallel to walls (Figure 3(a)). The perpendicular direction, in contrast, represents an energy barrier with the low surface energy of the structure as derived from Owens, Wendt, Rabel, and Kaelble calculations. The test liquid consequently forms an energyoptimized spherical geometry based on a "repelling effect" and the droplet is pinned (Figure 3(b)). These anisotropic energy barriers were not observed on the nonstructured 
TABLE 1: Contact angles and calculated surface energy values for structured and nonstructured (control) surfaces (pe: perpendicular, pa: parallel).

\begin{tabular}{|c|c|c|c|c|c|}
\hline & $\begin{array}{c}\mathrm{H}_{2} \mathrm{O} \\
\left(^{\circ}\right)\end{array}$ & $\begin{array}{c}\mathrm{CH}_{2} \mathrm{I}_{2} \\
\left(^{\circ}\right)\end{array}$ & $\begin{array}{c}\text { Surface energy } \\
(\mathrm{mN} / \mathrm{m})\end{array}$ & $\begin{array}{c}\text { Polar part } \\
(\mathrm{mN} / \mathrm{m})\end{array}$ & $\begin{array}{c}\text { Disperse part } \\
(\mathrm{mN} / \mathrm{m})\end{array}$ \\
\hline Nonstructured/pa & $75.4 \pm 2.6$ & $43.5 \pm 2.9$ & 43.4 & 5.6 & 37.8 \\
\hline Nonstructured/pe & $77.8 \pm 2.7$ & $44.6 \pm 3.0$ & 42.0 & 4.8 & 37.3 \\
\hline P1:1 Cubes/pa & $87.2 \pm 1.3$ & $61.4 \pm 2.8$ & 31.4 & 3.6 & 27.8 \\
\hline P1:1 Cubes/pe & $85.8 \pm 2.4$ & $60.3 \pm 2.5$ & 32.4 & 3.9 & 28.4 \\
\hline P1:5 Cubes/pa & $81.9 \pm 1.9$ & $59.8 \pm 1.9$ & 34.0 & 5.3 & 28.7 \\
\hline P1:5 Cubes/pe & $81.0 \pm 0.9$ & $59.3 \pm 2.7$ & 34.6 & 5.6 & 29.0 \\
\hline P1:1 Walls/pa & $131.9 \pm 3.9$ & $66.8 \pm 0.3$ & 27.1 & 2.4 & 24.7 \\
\hline P1:1 Walls/pe & $58.6 \pm 0.7$ & $32.9 \pm 1.4$ & 55.0 & 12.0 & 43.0 \\
\hline P1:5 Walls/pa & $126.4 \pm 3,7$ & $97.4 \pm 2.8$ & 9.6 & 0.0 & 9.6 \\
\hline P1:5 Walls/pe & $70.4 \pm 1.4$ & $58.5 \pm 1.4$ & 40.1 & 10.6 & 29.4 \\
\hline
\end{tabular}

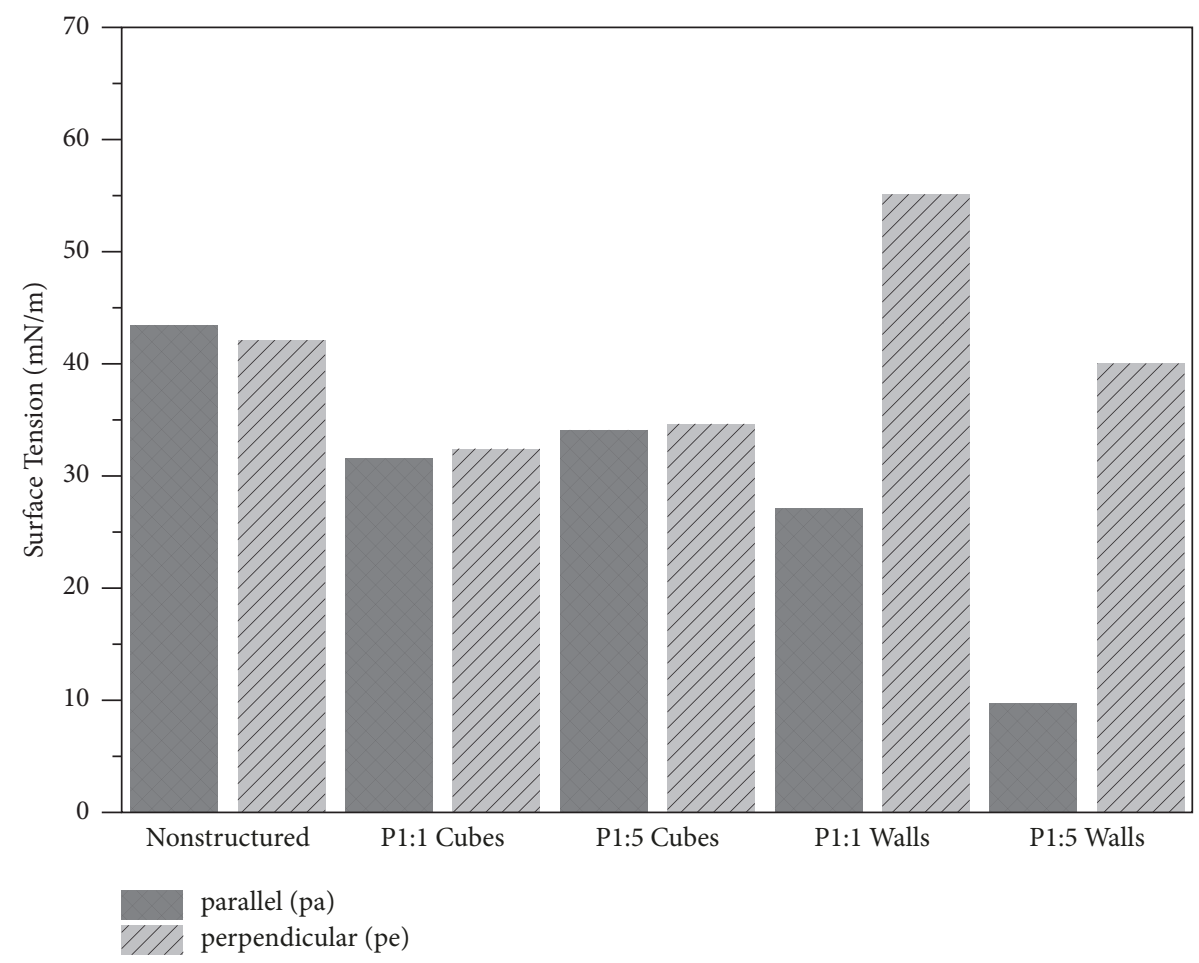

FIGURE 2: Surface tension depends on substrate topography. Calculated surface energy as function of substrate topography. Contact angles were measured perpendicular or parallel to nonstructured and specific surface structures.

control, on which the droplet formed similar shapes for both parallel and perpendicular measurements, indicating isotropic surface energy of the substrate (Figures 3(c)-3(d)).

Based on the theoretical considerations presented in $[50,51]$, different droplet volumes $(1$ to $5 \mu \mathrm{L})$ were used to define the wetting state of a water droplet on microstructured samples. The contact angles obtained are listed in Table 2 and displayed in Figure 4 as a function of droplet volume and substrate topography. With respect to the nonstructured PMMA surface, anisotropy was significant with $5 \mu \mathrm{L}$ of the test liquid $\left(\mathrm{H}_{2} \mathrm{O}\right.$, pe: $72^{\circ}$, pa: $\left.80^{\circ}\right)$ in comparison to $1 \mu \mathrm{L}$ of the test liquid $\left(\mathrm{H}_{2} \mathrm{O}\right.$, pe: $73^{\circ}$, pa: $\left.74^{\circ}\right)$. No significant anisotropy was observed on the surface with P1:1 cubic structure with increasing droplet volumes. However, with rising pitch (P1:5), the structured surface showed the same insignificant trend in anisotropy $\left(\mathrm{H}_{2} \mathrm{O}\right.$, pe: $90^{\circ}$, pa: $\left.76^{\circ}\right)$ as the nonstructured control. Walls exhibited significant anisotropy with the investigated drop volumes. Here we observed that structures with a smaller pitch exhibited higher anisotropy than structures with a larger pitch, whilst anisotropy was more pronounced with a smaller test liquid volume.

The results suggest that wetting behaviour on structured samples follows either a Wenzel (complete topography filling by test liquid) or a mixed wetting regimen (incomplete 
TABLE 2: Contact angles of water as a function of droplet volume and substrate topography.

\begin{tabular}{lccc}
\hline & $1 \mu \mathrm{L} \mathrm{H} \mathrm{H}_{2}\left(^{\circ}\right)$ & $2 \mu \mathrm{L} \mathrm{H}_{2} \mathrm{O}\left(^{\circ}\right)$ & $5 \mu \mathrm{L} \mathrm{H}{ }_{2} \mathrm{O}\left({ }^{\circ}\right)$ \\
\hline Nonstructured/pa & $73.4 \pm 0.6$ & $75.4 \pm 2.6$ & $72.4 \pm 2.0$ \\
\hline Nonstructured/pe & $73.8 \pm 1.6$ & $77.8 \pm 2.7$ & $80.1 \pm 2.9$ \\
\hline P1:1 Cubes/pa & $84.5 \pm 1.4$ & $87.2 \pm 1.3$ & $86.5 \pm 1.8$ \\
\hline P1:1 Cubes/pe & $80.2 \pm 1.2$ & $85.8 \pm 2.4$ & $83.7 \pm 1.0$ \\
\hline P1:5 Cubes/pa & $79.6 \pm 1.5$ & $81.9 \pm 1.9$ & $89.9 \pm 0.5$ \\
\hline P1:5 Cubes/pe & $78.9 \pm 1.9$ & $81.0 \pm 0.9$ & $75.5 \pm 2.7$ \\
\hline P1:1 Walls/pa & $135.9 \pm 0.8$ & $131.9 \pm 3.9$ & $134.1 \pm 3.5$ \\
\hline P1:1 Walls/pe & $50.3 \pm 1.8$ & $58.6 \pm 0.7$ & $65.6 \pm 0.8$ \\
\hline P1:5 Walls/pa & $137.4 \pm 1.0$ & $126.4 \pm 3.7$ & $119.6 \pm 3.0$ \\
\hline P1:5 Walls/pe & $65.5 \pm 1.5$ & $70.4 \pm 1.1$ & $73.5 \pm 3.1$ \\
\hline
\end{tabular}

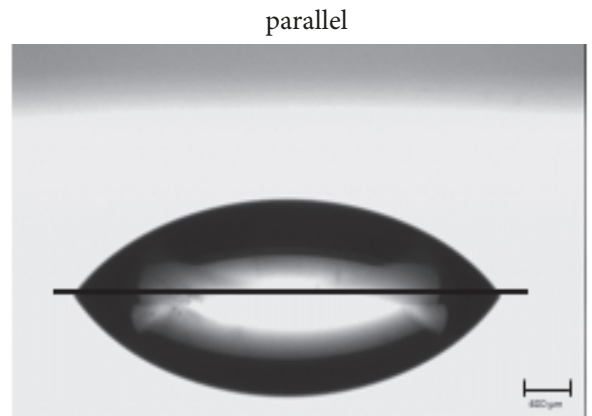

(a)

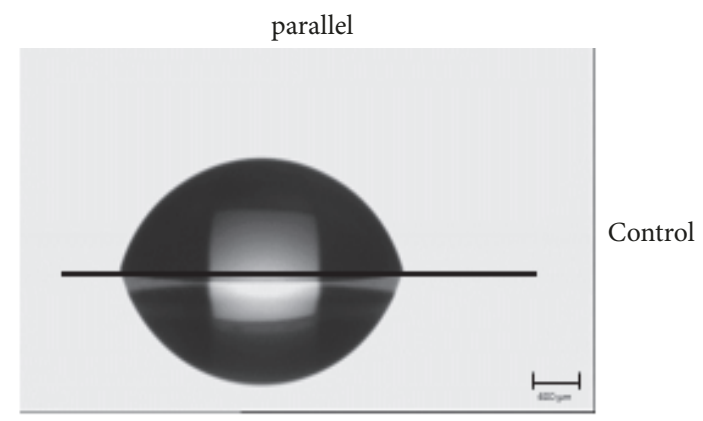

(c)

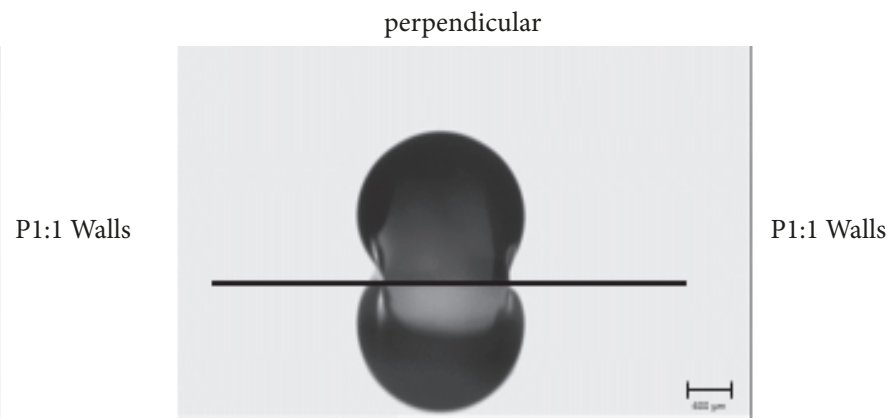

(b)

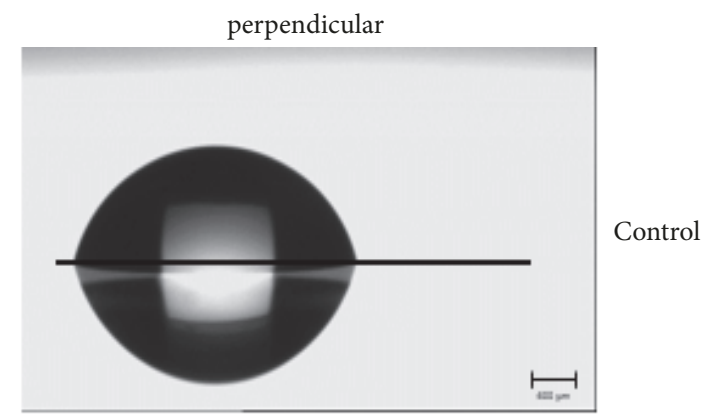

(d)

Figure 3: Energy optimized model of water droplets. Behaviour of water droplets on nonstructured control and P1:1 walls. (a) Water droplet parallel to P1:1 walls; (b) water droplet perpendicular to P1:1 walls; (c) water droplet on nonstructured control, parallel; (d) water droplet on nonstructured control, perpendicular.

filling of topography by test liquid). A further indication is provided by drops "sticking" to the structured surface when the substrate samples are tilted (at $45^{\circ}$ and $90^{\circ}$ angles) as suggested by Neuhaus et al. [51]. In the case of a full CassieBaxter regime, a drop with air trapped beneath it would slide off the surface due to a composite air-polymer substrate and thus reduced physical attachment to the (polar) polymer surface [52].

3.3. Cell Shape is Modulated by Microstructures. Specific drop shapes linked to a substrate by intermolecular forces are well documented for wetting regimens of liquids on heterogeneous surfaces [50-52]. According to Alberts et al. [2], changes in and of optimization of cell shape are driven by a minimization of total free energy and of the surface-to-volume ratio of the cell membrane. We therefore hypothesize that cells correlate their focal adhesion network and subsequently their shape on heterogeneous surfaces in a manner analogous to water drops with differences in boundary surface energy "energy barriers" to minimize total free energy. These energy barriers are also denoted by the above described contact angle measurements on nonstructured controls and structured PMMA substrates (Table 1).

The pluripotent human embryonal carcinoma cell line NTera2/cl.d1 (NT2/D1) which is able to differentiate into mature neurons [53] was chosen as model to test this. NT2/D1 


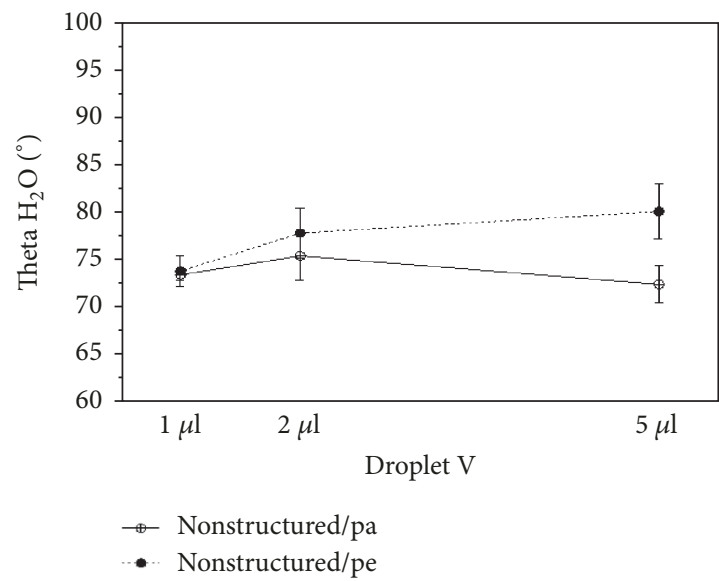

(a)

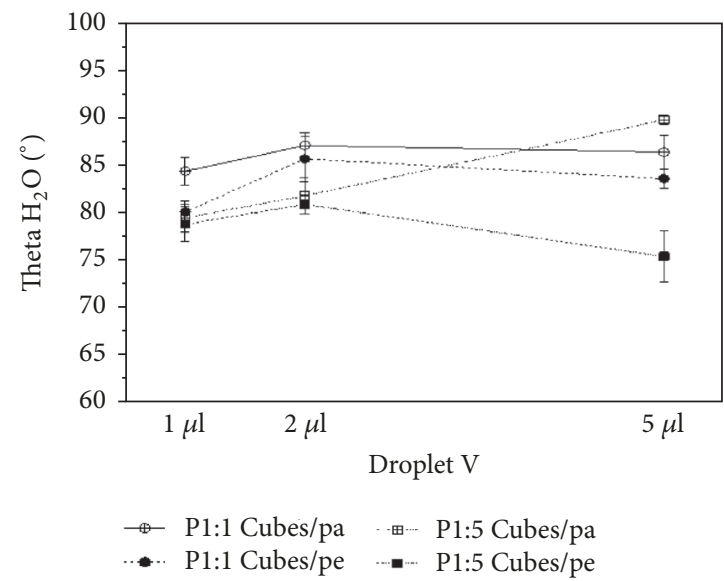

(b)

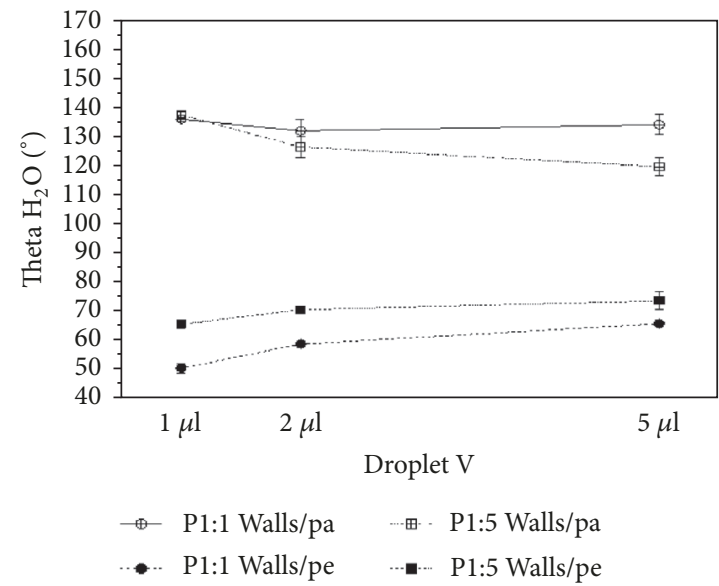

(c)

FIGURE 4: Water contact angles as function of droplet volume and substrate topography. (a) Nonstructured control, (b) cubes, and (c) walls.

precursors are commonly used as a model for neurogenesis [40] and have already shown promise for implementation in experimental [54-56] and clinical [57] cell replacement approaches. For a clearer presentation of our results we show a clear contrast between parallel (Figures 5(a1)-5(a5)) and perpendicular (Figures 5(b1)-5(b5)) water droplet behaviour and our observed NT2/D1 morphological changes (Figures $5(\mathrm{cl})-5(\mathrm{c} 5))$ on nonstructured control and microstructured PMMA substrates.

We observed striking PMMA structure-dependent morphological differences. Cells cultured on cubes P1:1, unlike those on the unstructured substrate, exhibited poor adherence. The few cells attached to the surface appeared "out of shape" indicating a loss of cellular integrity pointing to a repelling action of this surface structure (Figure 5(c2)). On cubic structure P1:5, cells appeared triangular or quadrangular shaped, sitting on the given cubes (Figure 5(c3)). Cells cultured on walls P1:1 and P1:5 appeared quadrangular and elongated, with alignment of the cytoskeleton along the underlying walls (Figures $5(c 4)+5(c 5)$ ).

At first sight, the quadrangular, elongated form adopted by NT2/D1 cells on wall-structured substrates appeared to resemble the morphological features of a more mature neuronal cell. We therefore evaluated the expression by these cells of three markers of advanced neuronal structural differentiation, namely, MAP2, NF200, and Tuj1 (ßIII Tubulin). None of these markers was, however, elevated in response to the different microstructured surfaces (Figure S2), eliminating an occurrence of molecular neuronal differentiation, during the observed time window, in contrast to the results reported by other groups [58-63]. We could not determine an involvement of different substrate microtopographies on cell differentiation as suggested, for example, by Schernthaner et al., for nanotopographies [64, 65]. However, these results were generated using endothelial cells; therefore we cannot directly compare different cells types and possible cell type related responses. Moreover, neuronal differentiation on structured surfaces would, however, probably need more time, since chemical induction of neuronal differentiation of NT2/D1 cells with retinoic acid takes around 6 weeks to produce fully differentiated neurons. Cultivation of undifferentiated cells for $48 \mathrm{~h}$ on the investigated structures thus appears unlikely to induce real effects on differentiation. The observed morphological changes were nevertheless profound 


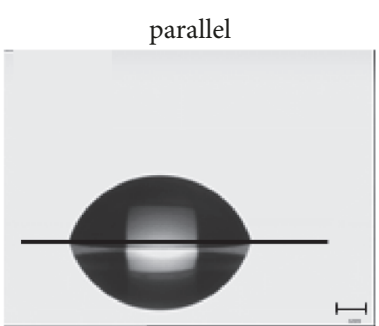

(a1)

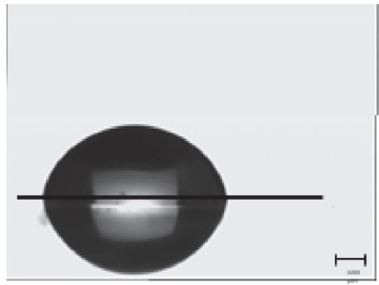

(a2)

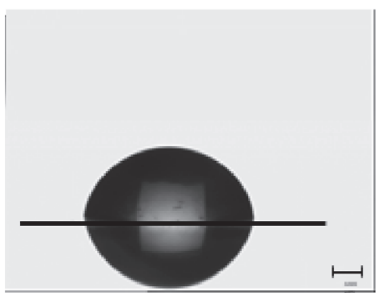

(a3)

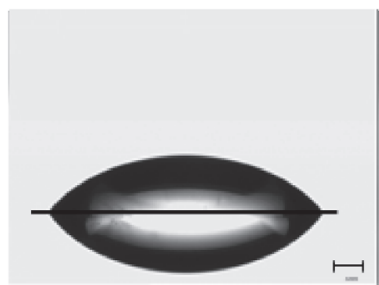

(a4)

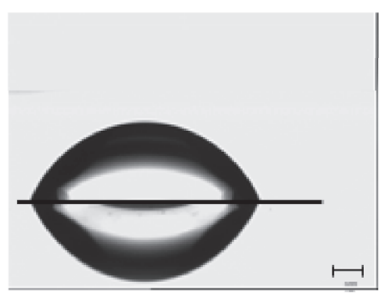

(a5)

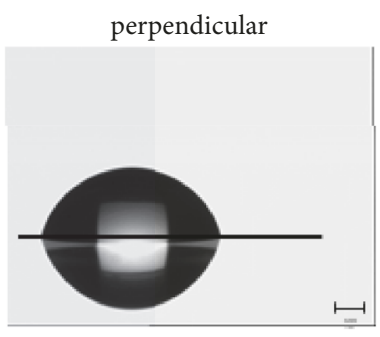

(b1)

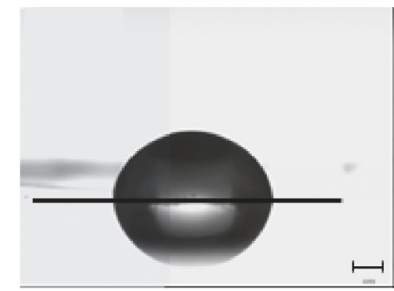

(b2)

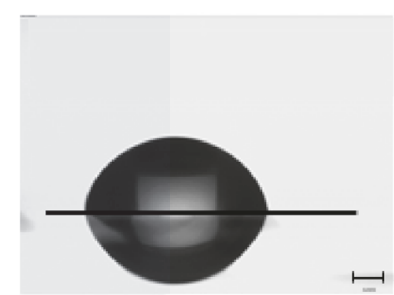

(b3)

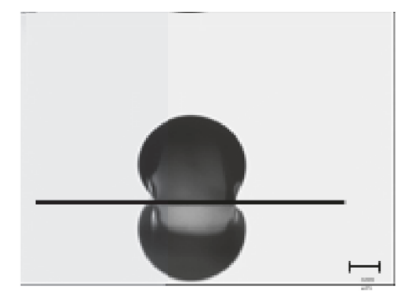

(b4)

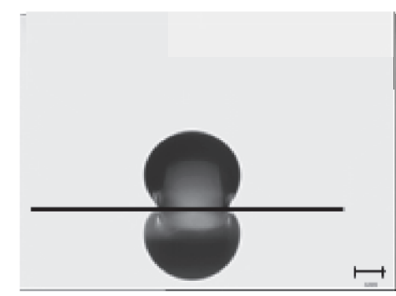

(b5)
NT2/D1

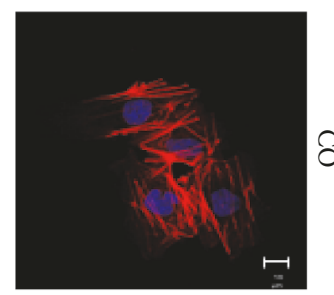

(c1)

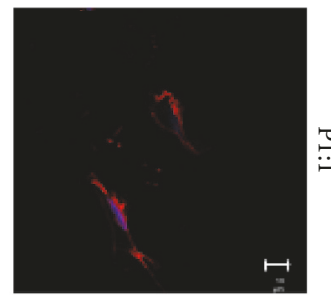

(c2)

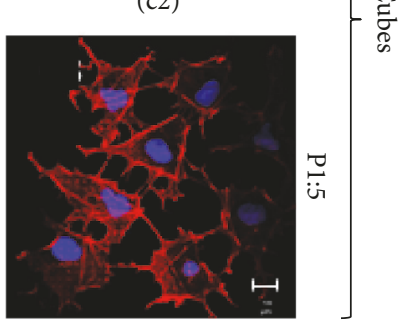

(c3)

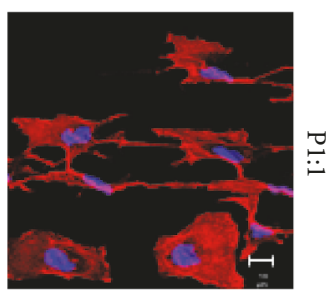

(c4)

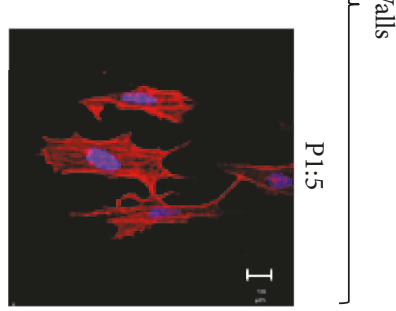

(c5)

FIGURE 5: The water drop model. Comparison between water droplet shapes and cell morphology of NT2/D1. (a1)-(a5): side view, parallel to walls reference; (b1)-(b5): side view, perpendicular to walls reference; (c1)-(c5): NT2/D1 cells in LSM top view on microstructures. Microstructures indicated on the right side. Scale bar $=10 \mu \mathrm{m}$.

and consequently do at least support the notion that cells per se respond to the underlying topography with morphological changes as previously described [3, 63, 66-72].

We therefore hypothesized that other cell types would respond similarly to substrate structure as also postulated by Janson et al. [67]. To test this, we cultivated a mouse preosteoblast cell line MC3T3-E1 that is used to model ECM induced osteoblast modulation on structured and nonstructured PMMA substrates. As shown in Figure 6 the morphological changes described above for NT2/D1 cells on the structured substrates were also observed with MC3T3E1 cells. Although osteoblasts are considered robust, these also exhibited poorer adherence to the cubic structure P1:1 than to the unstructured surface, with only a few inchoateshaped cells sticking to the surface, underlining the previously observed repellent action of this surface structure. Cells cultured on cube P1:5, in contrast, appeared triangular to quadrangular and more bipolar-shaped/elongated on 


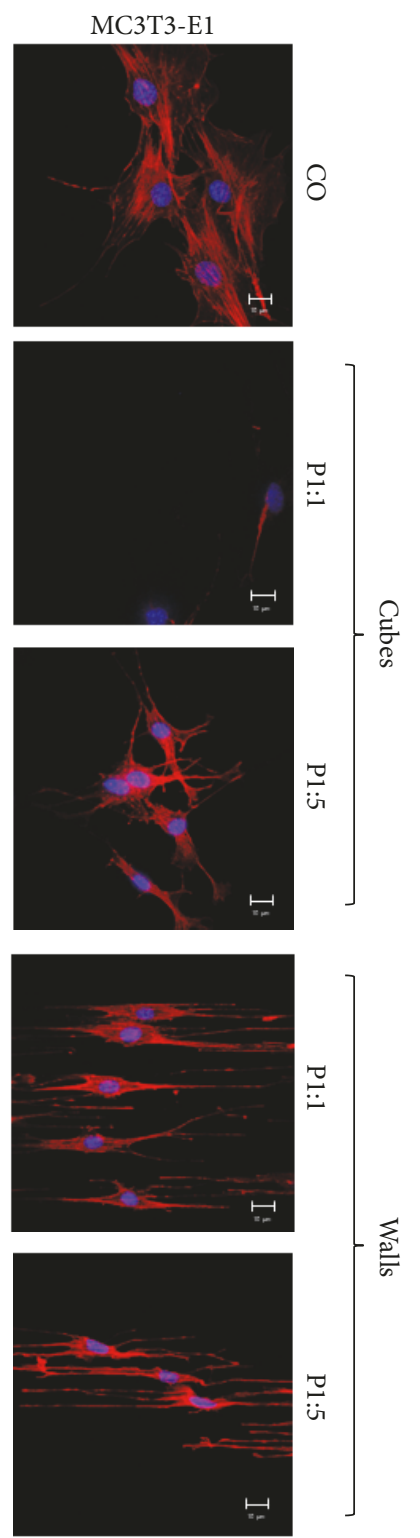

FIGURE 6: Cell morphology of MC3T3-E1 cells changes in response to the structured surface. LSM images of MC3T3-E1 cells on microstructures indicated on the right side. Scale bar $=10 \mu \mathrm{m}$.

walls P1:1 and P1:5. The intracellular network of interlinking filaments and tubules of the cytoskeleton again were adjusted to the given wall structure. Whilst the results were similar for both cell lines and thus support a cell type-independent mechanism, the observed elongation was noticeably more pronounced with MC3T3-E1 preosteoblasts than with NT2/D1 cells.

We thus interpret this to indicate that the mechanism underlying the pronounced elongation of MC3T3-E1 and NT2/D1 cells on walls is fundamentally the same as that causing the spreading of water droplets, that is, asymmetric energy barrier heights, displayed, for example, in a difference, between surface energies perpendicular $(55.1 \mathrm{mN} / \mathrm{m})$ and parallel $(27.1 \mathrm{mN} / \mathrm{m})$ to walls P1:1 (Table 1$)$.
An average isotropic water contact angle of $\leq 85^{\circ}$ and an average isotropic surface energy of $\geq 32 \mathrm{mN} / \mathrm{m}$ appear to be necessary for effective MC3T3-E1 and NT2/D1 cell adhesion, accounting for the repellent action of cubes P1:1 observed with both cell lines tested. Based on this, we postulate a "switch" for cell adhesion and subsequently cell growth through adjustment of cube periodicity $(\mathrm{P} 1: 1 \longrightarrow \mathrm{P} 1: 5)$ and consequently increased hydrophobicity.

Our simplified "water-drop model" presented here could describe a common physicochemical cause regarding the similar cell and droplet geometry observed on microstructures and nonstructured control and the cell adhesion of MC3T3-E1 and NT2/D1 cells. It seems that both phenomena appear to be based on surface energy barriers that differ in both direction and strength, as also described by Janson et al. [67]. The model could possibly account for the cell phenomena guided by anisotropic topographical cues discussed by Davidenko et al. [73], Mitchell et al. [74], and Thomson et al. [75] among other studies.

\section{Conclusion}

The aim of the present study was to gain basic knowledge of component behaviour on polymeric microstructures mimicking extracellular matrix topography. We thereby hypothesized a fundamental role in this for variable substrate surface energy associated with different surface topographies and consequently designed and investigated microstructures with pronounced differences in surface energy. PMMA was chosen as base polymer, structure design included cubes and walls at the micrometre scale, and structuring was established in appropriate demolding quality by injection molding.

Our results indicated no influence of microstructures on MC3T3-E1 and NT2/D1 cell differentiation within the observed time frame. A profound impact on adhesion and morphology was, however, observed, which was related to the influence of boundary surface energy. Comparison of two different cell types produced similar results, supporting cellindependent causality. For adequate adhesion, a maximisation of average isotropic water contact angle as well as minimisation of average isotropic surface energy appeared to be necessary. Thus, a "switch" to cell adhesion and subsequently to cell growth could be applied by adjusting cube periodicity. Contact angle measurements on the microstructures demonstrated enhanced surface energy anisotropy on wallstructured surfaces causing lengthwise spreading of the test liquid droplet analogous to cell elongation. Both phenomena appear to be based on variable surface energy barriers in direction and strength.

We, hence, propose a water drop model potentially providing a common physicochemical cause regarding MC3T3E1 and NT2/D1 cell adhesion and similar cell and droplet geometry on microstructures and nonstructured control.

\section{Data Availability}

The data used to support the findings of this study are available from the corresponding author upon request. 


\section{Disclosure}

Current affiliations of Christa Trattnig are as follows: RuprechtKarls-Universität Heidelberg, Institute for Anatomy and Cell Biology, Division for Medical Cell Biology, Heidelberg, Germany.

\section{Conflicts of Interest}

The authors declare that they have no conflicts of interest.

\section{Acknowledgments}

This work was mainly funded by the Austrian Research Promotion Agency (FFG) within the Project FFG No. 824915. Part of this study was performed at the Polymer Competence Center Leoben GmbH (PCCL, Austria) within the framework of the COMET K1 program of the Austrian Federal Ministry for Transport, Innovation, and Technology and of the Austrian Federal Ministry for Economy, Family, and Youth with contributions of Montanuniversität Leoben. PCCL is funded by the Austrian Government and the State Governments of Styria and Upper and Lower Austria. This work was supported by CAMed (COMET K-Project 871132) which is funded by the Austrian Federal Ministry of Transport, Innovation, and Technology (BMVIT) and the Austrian Federal Ministry for Digital and Economic Affairs (BMDW) and the Styrian Business Promotion Agency (SFG).

\section{Supplementary Materials}

Supplementary Figure 1: test system for cell laboratory. A: 4panel-slide with structure fields (left) and without structure fields as nanostructured control (right). B: 4-panelslide with Millipore adapter. C: assembled test system. Supplementary Figure 2: analysis of differentiation marker by RT-PCR. mRNA expression of A: NF200, B: MAP2, and C: Tuj1 in response to nonstructured control and structures as indicated in the figure. $\mathrm{n}=3$ biological replicates; error bars show standard error of the mean (SEM). (Supplementary Materials)

\section{References}

[1] J. K. Young, Introduction to Cell Biology, World Scientific, Singapore, 2010.

[2] B. Alberts, A. Johnson, J. Lewis et al., Molecular Biology of the Cell, Garland Science Taylor and Francis Group, New York, NY, USA, 2015.

[3] A. Atala and R. Lanza, Essentials of Stem Cell Biology, Academic Press, San Diego, CA, USA, 2014.

[4] A. S. G. Curtis, N. Gadegaard, M. J. Dalby, M. O. Riehle, C. D. W. Wilkinson, and G. Aitchison, "Cells react to nanoscale order and symmetry in their surroundings," IEEE Transactions on NanoBioscience, vol. 3, no. 1, pp. 61-65, 2004.

[5] C. Simitzi, A. Ranella, and E. Stratakis, "Controlling the morphology and outgrowth of nerve and neuroglial cells: The effect of surface topography," Acta Biomaterialia, vol. 51, pp. 21-52, 2017.
[6] S. Zangi, I. Hejazi, J. Seyfi, E. Hejazi, H. A. Khonakdar, and S. M. Davachi, "Tuning cell adhesion on polymeric and nanocomposite surfaces: Role of topography versus superhydrophobicity," Materials Science and Engineering C: Materials for Biological Applications, vol. 63, pp. 609-615, 2016.

[7] W. W. R. Araujo, F. S. Teixeira, G. N. da Silva et al., "Cell growth on 3D microstructured surfaces, Materials science engineering. C," Materials Science \& Engineering. C, Materials for Biological Applications, vol. 63, pp. 686-689, 2016.

[8] R. G. Flemming, C. J. Murphy, G. A. Abrams, S. L. Goodman, and P. F. Nealey, "Effects of synthetic micro- and nanostructured surfaces on cell behavior," Biomaterials, vol. 20, no. 6, pp. 573-588, 1999.

[9] M. M. Stevens and J. H. George, "Exploring and engineering the cell surface interface," Science, vol. 310, no. 5751, pp. 1135-1138, 2005.

[10] E. Martínez, E. Engel, J. A. Planell, and J. Samitier, "Effects of artificial micro- and nano-structured surfaces on cell behaviour," Annals of Anatomy = Anatomischer Anzeiger : Official Organ of the Anatomische Gesellschaft, vol. 191, no. 1, pp. 126-135, 2009.

[11] E. K. F. Yim and K. W. Leong, "Significance of synthetic nanostructures in dictating cellular response," Nanomedicine: Nanotechnology, Biology and Medicine, vol. 1, no. 1, pp. 10-21, 2005.

[12] S. A. Skoog, G. Kumar, R. J. Narayan, and P. L. Goering, "Biological responses to immobilized microscale and nanoscale surface topographies," Pharmacology \& Therapeutics, 2017.

[13] C. Frantz, K. M. Stewart, and V. M. Weaver, "The extracellular matrix at a glance," Journal of Cell Science, vol. 123, no. 24, pp. 4195-4200, 2010.

[14] M. J. Dalby, D. Giannaras, M. O. Riehle, N. Gadegaard, S. Affrossman, and A. S. G. Curtis, "Rapid fibroblast adhesion to $27 \mathrm{~nm}$ high polymer demixed nano-topography," Biomaterials, vol. 25, no. 1, pp. 77-83, 2004.

[15] M. J. Dalby, M. O. Riehle, H. Johnstone, S. Affrossman, and A. S. G. Curtis, "Investigating the limits of filopodial sensing: A brief report using SEM to image the interaction between 10 $\mathrm{nm}$ high nano-topography and fibroblast filopodia," Cell Biology International, vol. 28, no. 3, pp. 229-236, 2004.

[16] M. J. Dalby, M. O. Riehle, H. J. H. Johnstone, S. Affrossman, and A. S. G. Curtis, "Polymer-demixed nanotopography: Control of fibroblast spreading and proliferation," Tissue Engineering Part A, vol. 8, no. 6, pp. 1099-1108, 2002.

[17] M. J. Dalby, S. Childs, M. O. Riehle, H. J. H. Johnstone, S. Affrossman, and A. S. G. Curtis, "Fibroblast reaction to island topography: changes in cytoskeleton and morphology with time," Biomaterials, vol. 24, no. 6, pp. 927-935, 2003.

[18] K. L. Elias, R. L. Price, and T. J. Webster, "Enhanced functions of osteoblasts on nanometer diameter carbon fibers," Biomaterials, vol. 23, no. 15, pp. 3279-3287, 2002.

[19] X. M. Mo, C. Y. Xu, M. Kotaki, and S. Ramakrishna, "Electrospun P(LLA-CL) nanofiber: a biomimetic extracellular matrix for smooth muscle cell and endothelial cell proliferation," Biomaterials, vol. 25, no. 10, pp. 1883-1890, 2004.

[20] R. L. Price, M. C. Waid, K. M. Haberstroh, and T. J. Webster, "Selective bone cell adhesion on formulations containing carbon nanofibers," Biomaterials, vol. 24, no. 11, pp. 1877-1887, 2003.

[21] C. Y. Xu, R. Inai, M. Kotaki, and S. Ramakrishna, "Aligned biodegradable nanofibrous structure: a potential scaffold for 
blood vessel engineering," Biomaterials, vol. 25, no. 5, pp. 877886, 2004.

[22] H. Yoshimoto, Y. M. Shin, H. Terai, and J. P. Vacanti, "A biodegradable nanofiber scaffold by electrospinning and its potential for bone tissue engineering," Biomaterials, vol. 24, no. 12, pp. 2077-2082, 2003.

[23] A. Thapa, D. C. Miller, T. J. Webster, and K. M. Haberstroh, "Nano-structured polymers enhance bladder smooth muscle cell function," Biomaterials, vol. 24, no. 17, pp. 2915-2926, 2003.

[24] R.-D. Chien, "Hot embossing of microfluidic platform," International Communications in Heat and Mass Transfer, vol. 33, no. 5, pp. 645-653, 2006.

[25] M. Heckele, W. Bacher, and K. D. Müller, "Hot embossing - The molding technique for plastic microstructures," Microsystem Technologies, vol. 4, no. 3, pp. 122-124, 1998.

[26] M. Sahli, J.-C. Gelin, and T. Barrière, "Replication of microchannel structures in WC-Co feedstock using elastomeric replica moulds by hot embossing process," Materials Science and Engineering C: Materials for Biological Applications, vol. 55, pp. 252-266, 2015.

[27] M. Worgull, "Hot embossing," in Theory and Technology of Microreplication, William Andrew, 2009.

[28] Y. Zhao and T. Cui, "Fabrication of high-aspect-ratio polymerbased electrostatic comb drives using the hot embossing technique," Journal of Micromechanics and Microengineering, vol. 13, no. 3, pp. 430-435, 2003.

[29] R. Hoyle, "Creating micro and nano structures in polymers by moulding," Medical Device Technology, vol. 18, no. 5, pp. 18-20, 2007.

[30] C. Jeggy, Process to Modelling: From Process to Modelling, The Presses Universitaires De Louvain, 2004.

[31] M. Koc and T. Ozel, Micro-Manufacturing: Design and Manufacturing of Micro-Products, John Wiley \& Sons, 2011.

[32] W. Michaeli, A. Rogalla, and C. Ziegmann, "Processing technologies for the injection moulding of hybrid microstructures," Macromolecular Materials and Engineering, vol. 279, pp. 42-45, 2000.

[33] W. Michaeli, A. Spennemann, and R. Gärtner, "New plastification concepts for micro injection moulding," Journal of Polymer Engineering, vol. 24, no. 1-3, 2004.

[34] W. Michaeli and C. Ziegmann, "Micro assembly injection moulding for the generation of hybrid microstructures," Microsystem Technologies, vol. 9, no. 6-7, pp. 427-430, 2003.

[35] R. H. Todd, D. K. Allen, and L. Alting, Manufacturing Processes Reference Guide, Industrial Press, New York, NY, USA, 1994.

[36] S. Dimov and W. Menz, 4M 2005 - First International Conference on Multi-Material Micro Manufacture, Elsevier, 2005.

[37] M. J. Jackson, Micro and Nanomanufacturing, Springer Science \& Business Media, 2007.

[38] J. H. Smith, "Micromachining and microfabrication process technology," Society of Photo Optical, 1998.

[39] L. Xie, T. Niesel, M. Leester-Schädel, G. Ziegmann, and S. Büttgenbach, "A novel approach to realize the local precise variotherm process in micro injection molding," Microsystem Technologies, vol. 19, no. 7, pp. 1017-1023, 2013.

[40] S. Haubenwallner, M. Katschnig, U. Fasching et al., "Effects of the polymeric niche on neural stem cell characteristics during primary culturing," Journal of Materials Science: Materials in Medicine, vol. 25, no. 5, pp. 1339-1355, 2014.

[41] 2014, N.N., Data Sheet Delpet 70NH.
[42] G. Fu, N. H. Loh, S. B. Tor, B. Y. Tay, Y. Murakoshi, and R. Maeda, "A variotherm mold for micro metal injection molding," Microsystem Technologies, vol. 11, no. 12, pp. 1267-1271, 2005.

[43] T. Lucyshyn, T. Struklec, M. Burgsteiner, G. Graninger, and C. Holzer, "Research in manufacturing of micro-structured injection molded polymer parts," in Proceedings of the AIP Conference Proceedings, vol. 1695, p. 020014, AIP Publishing LLC, 2015.

[44] 2017, N.N., Drop Shape Analysis: Glossary, https://www.kruss .de/services/education-theory/glossary/drop-shape-analysis/.

[45] D. K. Owens and R. C. Wendt, "Estimation of the surface free energy of polymers," Journal of Applied Polymer Science, vol. 13, no. 8, pp. 1741-1747, 1969.

[46] W. Rabel, "Einige aspekte der benetzungstheorie und ihre anwendung auf die untersuchung und veränderung der oberflächeneigenschaften von polymeren," Farbe und Lack, no. 77, pp. 997-1006, 1971.

[47] J. M. Schakenraad, H. J. Busscher, C. R. H. Wildevuur, and J. Arends, "The influence of substratum surface free energy on growth and spreading of human fibroblasts in the presence and absence of serum proteins," Journal of Biomedical Materials Research Part B: Applied Biomaterials, vol. 20, no. 6, pp. 773784, 1986.

[48] A. Ranella, M. Barberoglou, S. Bakogianni, C. Fotakis, and E. Stratakis, "Tuning cell adhesion by controlling the roughness and wettability of 3D micro/nano silicon structures," Acta Biomaterialia, vol. 6, no. 7, pp. 2711-2720, 2010.

[49] T. Irish, Surface energy data for PMMA, CAS \#9011-14-7, http://www.accudynetest.com/polymer_surface_data/pmma_ polymethylmethacrylate.pdf.

[50] E. Bormashenko, "Progress in understanding wetting transitions on rough surfaces," Advances in Colloid and Interface Science, vol. 222, pp. 92-103, 2015.

[51] S. Neuhaus, N. D. Spencer, and C. Padeste, "Anisotropic wetting of microstructured surfaces as a function of surface chemistry," ACS Applied Materials \& Interfaces, vol. 4, no. 1, pp. 123-130, 2012.

[52] E. Martines, K. Seunarine, H. Morgan, N. Gadegaard, C. D. W. Wilkinson, and M. O. Riehle, "Superhydrophobicity and superhydrophilicity of regular nanopatterns," Nano Letters, vol. 5, no. 10, pp. 2097-2103, 2005.

[53] S. J. Pleasure and V. M. Lee, "NTera 2 cells: a human cell line which displays characteristics expected of a human committed neuronal progenitor cell," Journal of Neuroscience Research, vol. 35 , no. 6, pp. 585-602, 1993.

[54] J. Croitoru-Lamoury, K. R. Williams, F. M. J. Lamoury et al., "Neural transplantation of human MSC and NT2 cells in the twitcher mouse model," Cytotherapy, vol. 8, no. 5, pp. 445-458, 2006.

[55] G. Podrygajlo, C. Wiegreffe, M. Scaal, and G. Bicker, "Integration of human model neurons (NT2) into embryonic chick nervous system," Developmental Dynamics, vol. 239, no. 2, pp. 496-504, 2010.

[56] Y. Zhao and S. Wang, "Human NT2 neural precursor-derived tumor-infiltrating cells as delivery vehicles for treatment of glioblastoma," Human Gene Therapy, vol. 21, no. 6, pp. 683-694, 2010.

[57] P. T. Nelson, D. Kondziolka, L. Wechsler et al., "Clonal human (hNT) neuron grafts for stroke therapy," The American Journal of Pathology, vol. 160, no. 4, pp. 1201-1206, 2002. 
[58] K. Kolind, D. Kraft, T. Bøggild et al., "Control of proliferation and osteogenic differentiation of human dental-pulp-derived stem cells by distinct surface structures," Acta Biomaterialia, vol. 10, no. 2, pp. 641-650, 2014.

[59] G. Kumar, M. S. Waters, T. M. Farooque, M. F. Young, and C. G. Simon, "Freeform fabricated scaffolds with roughened struts that enhance both stem cell proliferation and differentiation by controlling cell shape," Biomaterials, vol. 33 , no. 16, pp. 40224030, 2012 .

[60] L. E. McNamara, R. J. McMurray, M. J. P. Biggs, F. Kantawong, R. O. C. Oreffo, and M. J. Dalby, "Nanotopographical control of stem cell differentiation," Journal of Tissue Engineering, vol. 2010, article 120623, Article ID 120623, 2010.

[61] J. Mitra, S. Jain, A. Sharma, and B. Basu, "Patterned growth and differentiation of neural cells on polymer derived carbon substrates with micro/nano structures in vitro," Carbon, vol. 65, pp. 140-155, 2013.

[62] F. Pan, M. Zhang, G. Wu et al., "Topographic effect on human induced pluripotent stem cells differentiation towards neuronal lineage," Biomaterials, vol. 34, no. 33, pp. 8131-8139, 2013.

[63] I. Tonazzini, S. Meucci, P. Faraci, F. Beltram, and M. Cecchini, "Neuronal differentiation on anisotropic substrates and the influence ofnanotopographical noise on neurite contact guidance," Biomaterials, vol. 34, no. 25, pp. 6027-6036, 2013.

[64] M. Schernthaner, G. Leitinger, H. Wolinski et al., "Enhanced $\mathrm{Ca} 2+$ entry and tyrosine phosphorylation mediate nanostructure-induced endothelial proliferation," Journal of Nanomaterials, vol. 2013, 10 pages, 2013.

[65] M. Schernthaner, B. Reisinger, H. Wolinski et al., "Nanopatterned polymer substrates promote endothelial proliferation by initiation of $\beta$-catenin transcriptional signaling," Acta Biomaterialia, vol. 8, no. 8, pp. 2953-2962, 2012.

[66] C. Gray, A. Boyde, and S. J. Jones, “Topographically induced bone formation in vitro: Implications for bone implants and bone grafts," Bone, vol. 18, no. 2, pp. 115-123, 1996.

[67] I. A. Janson, Y. P. Kong, and A. J. Putnam, "Nanotopographic substrates of poly (methyl methacrylate) do not strongly influence the osteogenic phenotype of mesenchymal stem cells in vitro," PLoS ONE, vol. 9, no. 3, article e90719, 2014.

[68] H. S. Koh, T. Yong, C. K. Chan, and S. Ramakrishna, "Enhancement of neurite outgrowth using nano-structured scaffolds coupled with laminin," Biomaterials, vol. 29, no. 26, pp. 35743582, 2008.

[69] L. Qi, N. Li, R. Huang et al., "The effects of topographical patterns and sizes on neural stem cell behavior," PLOS ONE, vol. 8, no. 3, article e59022, 2013.

[70] J. B. Recknor, J. C. Recknor, D. S. Sakaguchi, and S. K. Mallapragada, "Oriented astroglial cell growth on micropatterned polystyrene substrates," Biomaterials, vol. 25, no. 14, pp. 27532767, 2004.

[71] M. Schindler, I. Ahmed, J. Kamal et al., "A synthetic nanofibrillar matrix promotes in vivo-like organization and morphogenesis for cells in culture," Biomaterials, vol. 26, no. 28, pp. 5624-5631, 2005.

[72] L. Yao, S. Wang, W. Cui et al., "Effect of functionalized micropatterned PLGA on guided neurite growth," Acta Biomaterialia, vol. 5, no. 2, pp. 580-588, 2009.

[73] N. Davidenko, T. Gibb, C. Schuster et al., "Biomimetic collagen scaffolds with anisotropic pore architecture," Acta Biomaterialia, vol. 8, no. 2, pp. 667-676, 2012.

[74] G. R. Mitchell and A. Tojeira, "Role of anisotropy in tissue engineering," Procedia Engineering, vol. 59, pp. 117-125, 2013.
[75] S. E. Thomson, C. Charalambous, C.-A. Smith et al., "Microtopographical cues promote peripheral nerve regeneration via transient mTORC2 activation," Acta Biomaterialia, vol. 60, pp. 220-231, 2017. 


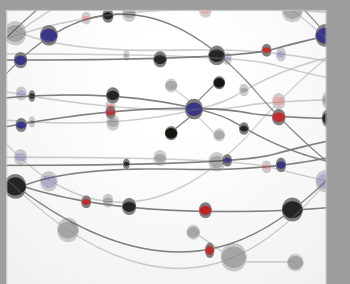

The Scientific World Journal
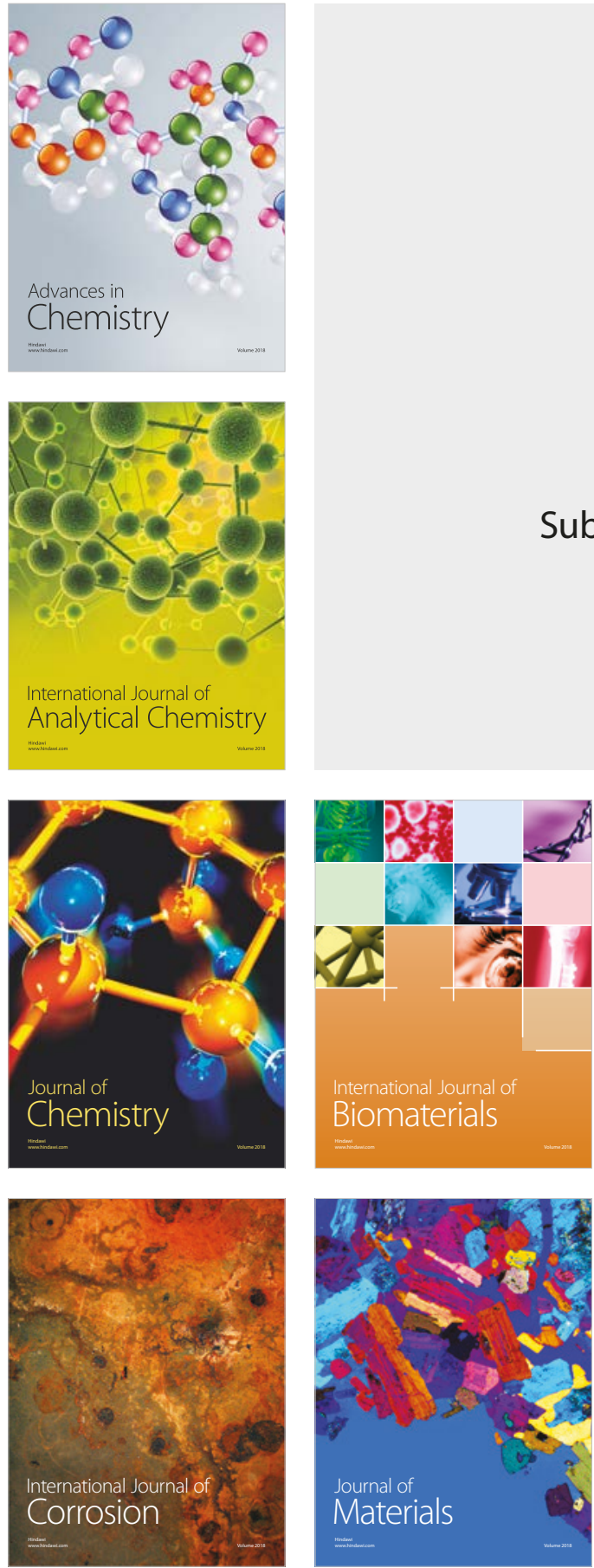

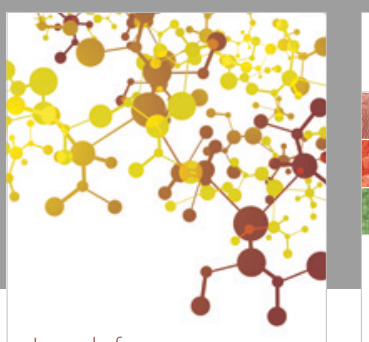

Journal of

Applied Chemistry
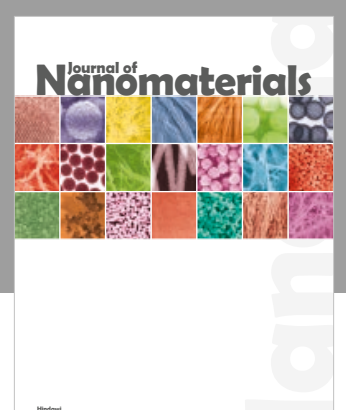

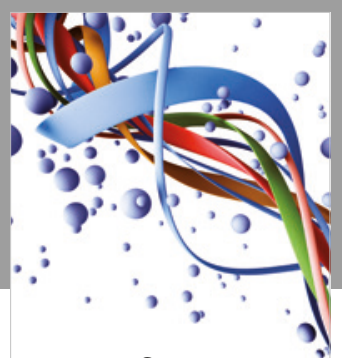

Scientifica

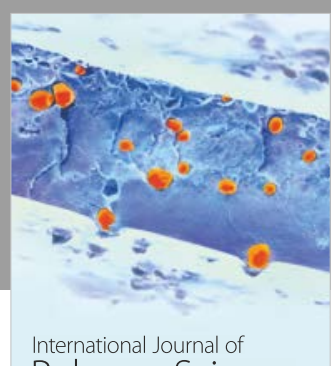

Polymer Science

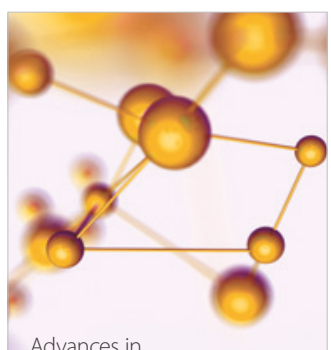

Physical Chemistry
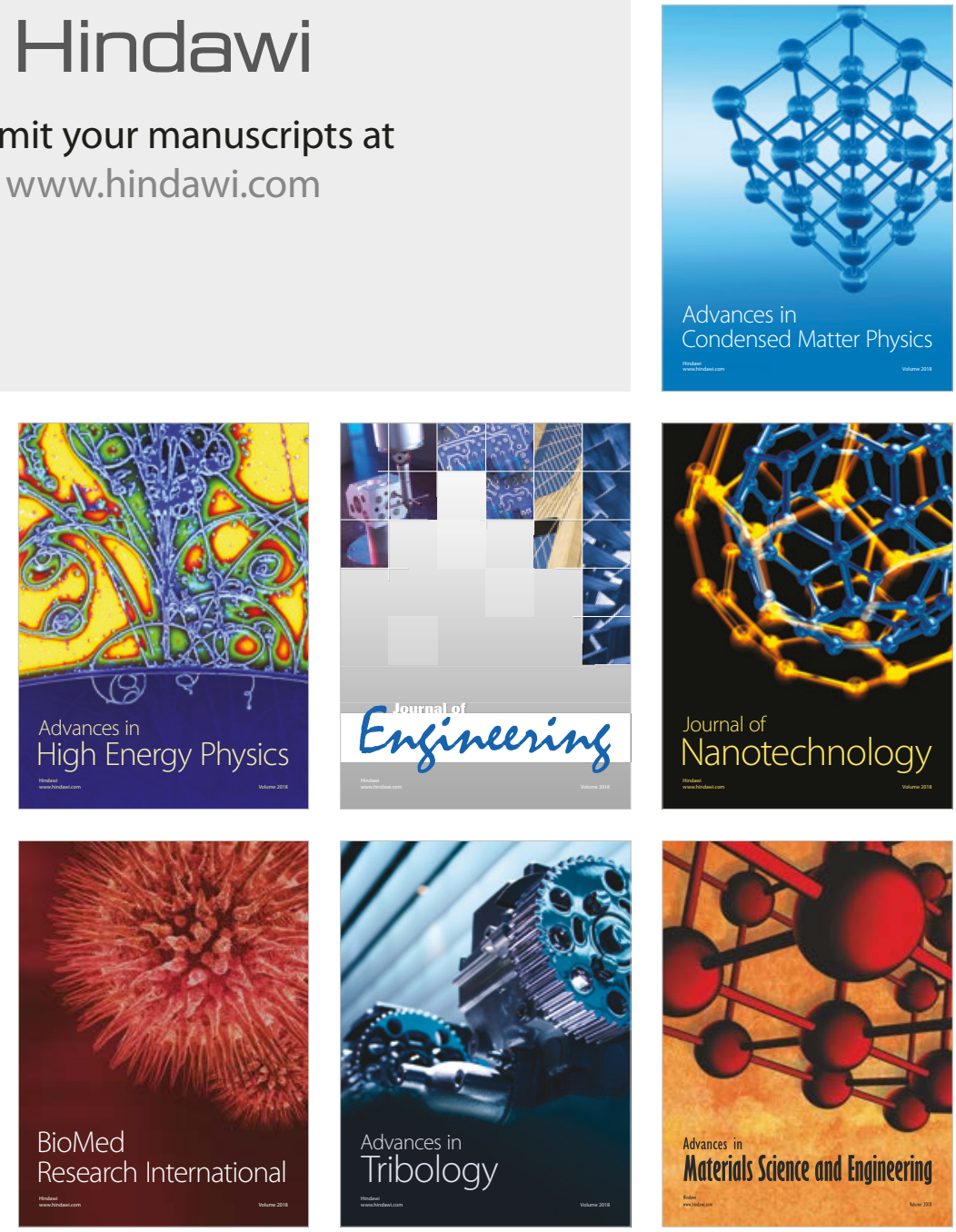